\title{
Exploring Grammatical Errors in Teaching Materials
}

\author{
Peace Chinwendu Israel \\ University of Education, Winneba, Ghana \\ Email: Peacenwendu1@yahoo.co.uk
}

How to cite this paper: Israel, P. C. (2020). Exploring Grammatical Errors in Teaching Materials. Open Journal of Modern Linguistics, 10, 620-633.

https://doi.org/10.4236/ojml.2020.105038

Received: September 18, 2020

Accepted: October 27, 2020

Published: October 30, 2020

Copyright $\odot 2020$ by author(s) and Scientific Research Publishing Inc. This work is licensed under the Creative Commons Attribution International License (CC BY 4.0).

http://creativecommons.org/licenses/by/4.0/

(c) (i) Open Access

\begin{abstract}
This study examined lexico-syntactic errors in selected textbooks written by Nigerians. The focus was on textbooks published by Vanity Publishers/Press. Through the purposive sampling technique, six textbooks were selected and the design was content analysis. Lexico-syntactic errors were identified, classified and analysed. The findings revealed the following error types: modification problems, prepositional and verb particles usage problems, concord errors, lexical problems, alteration of grammatical property of collocational items and restructuring of parallel sentences. These errors were not different from those identified over the years in students' essays and exam scripts. Therefore, the findings buttressed my argument that students are merely the conveyor belt of errors contained in teaching materials and that one can analyse students' errors in tandem with errors contained in the very materials they use in learning.
\end{abstract}

\section{Keywords}

Nigerian English, English as a Second Language, Error Analysis

\section{Introduction}

The last few decades have seen a tremendous growth in the role of the English language around the world. Today, $85 \%$ of the world's international organizations use English as their official language in international communication (Crystal, 1997). Language is a very important instrument for communication and English language in particular has facilitated the development of global networking, technological advancement and most importantly teaching and learning in the world over. In Nigeria, some of the current challenges in education are directed towards access, quality of teachers, equity and equality, funding and most importantly the quality of teaching materials. This paper therefore 
aims to explore the quality of teaching materials (textbooks) written by Nigerian authors and are used in the classroom teaching in Nigerian schools. It takes a critical look at the grammaticalness or otherwise of the textbooks and examines how this affects the quality of teaching and learning and the general communicative competence of the students.

\section{Key Concepts}

ESL: English as a Second Language (ESL) is the use or study of English by speakers with different native languages. It is taught all over the world under many circumstances. The teaching of ESL began in the 15th century with the advent of England's increased trading and colonisation throughout the world. The English had expanded their trade routes and needed to communicate with those with whom they were trading. English became the lingua franca, the common language of those doing business with the British. It was not until a few centuries later, however, that formal English instruction came into play. Kachru as cited in Faleke, Abaya \& Ahamed (2016) has divided the English-speaking countries of the world into three broad types, which he symbolizes by placing them in three concentric rings; The Inner Circle: These countries are the traditional bases of English, where it is the native/primary language, e.g. Great Britain and Ireland, the United States of America, Australia and New Zealand; The Outer or Extended Circle: These countries represent the earlier spread of English in non-native contexts, where the language is used in running the country's leading institutions and administrations, where it plays a second-language role in a multilingual society, e.g. Nigeria, Singapore, India, and about 50 other territories; The Expanding Circle: This includes countries that represent the importance of English as an international language though they have no history of colonisation and English has no special administrative status in these countries, e.g. China, Japan, Poland and a growing number of other states. This is also known as English as a Foreign Language (EFL). The outer or extending circle is the most sensitive to the global status of English. It is here that English performs several functional roles such as the language of social interaction, government, commerce and industry, mass media, politics, law, and language of education. Like most former British colonies, English is one of the greatest legacies bequeathed to the people of Nigeria at the end of colonisation (Rotimi, 2012).

Whenever a language functions as a borrowed second language, problems of usage are bound to arise. This is because when a language moves out of its original speech community, it is inevitable to have some super-imposed linguistic features and friction resulting from the meeting of two systems and cultural patterns. In Nigeria, such problems take different forms and are usually traceable to linguistic, educational, social, political and historical factors/constraints.

Educational constraints include the poor quality of teaching and teaching materials, and the non-availability of qualified teachers. Books, which are veritable teaching materials, play a vital role in individual and national development (Israel, 2012). They are a dependable source of growth for developing countries towards industrialization; yet, not all societies take the issue of quality of books 
in their schools seriously. Ker (2009) notes that Nigeria being one of such societies, has experienced a negative impact on the quality and quantity of education given to its citizens.

The contact situation between English and the numerous indigenous Nigerian languages (with all its sociolinguistic implications, including interference and the resulting bilingualism/multilingualism) played a crucial role in shaping the quality of books published in Nigeria. Moreover, when the English language (being outside its native environment) continues to be taught by non-native speakers, who were themselves taught by non-native speakers, there is bound to be deviations from the norm in usage which can easily be reflected in the quality of textbooks in circulation (Olagoke, 1981; Odumah \& Ohiare, 2016).

Furthermore, at school the learner is taught mostly by teachers to whom the language is also a second language and who, therefore, have not quite completely escaped the linguistic constraints such as a limited vocabulary range in their repertoire; a certain degree of insensitivity to the different levels of the language-formal, informal, familiar, colloquial; and the inherent syntactic, phonological and semantic peculiarities of the target language itself. And as it is theoretically unattainable for a learner to rise above the general level of competence of his own teacher, the problem becomes self-compounding since the teachers' own shortcomings are also transferred to the learners in the teaching process in addition to relatively few teachers having to cater for unmanageably outsized classes of learners (Egyir-Hagan, 2019). Again, the natural language skill development sequence of listening-speaking-reading-writing appears not to be acquired in the proper order by many Nigerian speakers/users of English (Adetugbo, 1979). This deficiency in language use easily manifests itself in the areas of phonology, syntax, lexis and semantics-with "syntax and lexis perhaps constituting the areas with the greatest incidence of interference..." (Okoro, 1980). This is the background against which this study is undertaken.

\section{English in Nigeria}

The beginning of the use of English in Nigeria can be traced back to the early nineteenth century when freed slaves of Nigerian origin returned to Nigeria following the abolition of slave trade. Many of the freed slaves of Nigerian origin had learnt English from abroad. Later, after the colonisation of Nigeria by the British, Nigeria used the language for administration. English then became prominent in the educational system and was used for official purposes. It also became elitist, symbolised by a few privileged Nigerians who were the civil servants and who served as models for indigenes who sought after formal education.

The use of English in Nigeria survived the departure of the colonial administrators as the language of administration. Several years after independence, English has assumed a more important status in Nigeria, and being one of the after effects of colonialism, knowing English has become a yardstick for the measurement of self-worth and self-actualisation (King-Aribisala, 2012).

In a situation where English is in contact with many local languages, and 
where English is a second language, it is to be expected that the kind of English found will be different from the varieties of English spoken in countries where English is native. The point about English in Nigeria is not just that it is different from British English or American English; it is rather that there are several varieties of English "ranging from something very near standard English to the patois of the market place" (Grieve, 1966). This eventually prompted a variety of English known as "Nigerian English". This variety of English is meant to serve as a term which is to cover the diverse kinds of peculiarities which is prominent at the lexical, syntactic, phonological and semantic levels of the English language that has served various functions in Nigeria. It enjoys unequivocal acceptance as a legitimate variety of the world Englishes and also occupies a respectable place among the "New Englishes" (Ubahakwe, 1979; Kachru, 1982; Jowitt, 1991; Bamgbose et al., 1995; Awonusi \& Babalola, 2004; Dadzie, 2004).

\section{Aim and Objectives}

The general aim of this paper is to draw attention to the declining standard of English in textbooks authored by Nigerians with a view to arresting its negative consequences.

The specific objectives are as follows:

- To identify and analyse lexico-syntactic errors in selected textbooks written by Nigerian authors;

- To recommend possible ways to resolve this problem.

\section{Theoretical Framework}

This study is based on the framework of Error Analysis (Corder, 1967; Richards, 1971; Dulay \& Burt, 1974). The concept, Error Analysis, has the proven capacity to adequately handle natural language data such as that which is dealt with here. It is also an effective method of exhaustively accounting for many of the errors in a corpus in any identified level of language analysis, here the levels of lexis and syntax (Chomsky, 1957; Darus, 2009).

Error analysis is the study of the learner's error, which can be observed, analysed and classified to reveal something within the learner. Richard (cited in Emmaryana, 2010) states that error analysis may be carried out in order to:

1) Find out how well someone knows a language.

2) Find out how a person learns a language

3) Obtain information on common difficulties in language learning as an aid in teaching or in the preparation of teaching materials.

To James (1998), error analysis is the process of determining the incidence, natural causes and consequences of unsuccessful language. Crystal (cited in Heydari, 2012), explains that error analysis is a technique for identifying, classifying and systematically interpreting the unacceptable forms produced by someone learning a foreign language using any of the principles and procedures provided by linguistics. Therefore, analysis of the learners' error gives the teach- 
er evidence of the learners' competence in the foreign language. It also helps the teacher to gain information concerning learner's difficulties at different levels and provides useful material for correctness and competence.

\section{Methodology}

This is an exploratory study which carried out a content analysis of the selected textbooks written by Nigerian authors. It aims at identifying and characterizing linguistic errors in textbooks written and published in Nigeria by Nigerians and use in teaching in various schools in Nigeria.

The following criteria guided the selection of the textbooks:

1) The textbooks were written by Nigerians.

2) The authors are at least graduates from a Nigerian university or polytechnic.

3) The authors acquired their primary, secondary and tertiary education in Nigeria.

4) The authors are graduates in the field they wrote on.

5) The textbooks are written for academic purposes.

6) The textbooks are used for tertiary education.

7) The textbooks were published in Nigeria.

Through the purposive sampling technique, the selected textbooks are:

- A Handbook on the Use of English for Tertiary Institutions by Abiola Akinkugbe \& Abla Ero-Philips, Published by Mesi-Kaka (Nig.) Co. Shomolu, Lagos, Nigeria in 1996. (Textbook 1)

- Elements of Insurance by Remi O. Oluoma, published by Ofas Investment Limited, 2A, Onafeko Street, Akoka, Yaba, Lagos in 2006. (Textbook 2)

- Library Education: a Handbook on Library Use by MolokwuUgochi E., published by T-Excel Publishers, 14, Awofola Street, Akoka, Lagos, Nigeria in 2006. (Textbook 3)

- Principles of Nigerian Law \& Legal Practice Volume 1 by Nwoha S. Aneke, published by John Jacob's Classic Publishers Ltd. Plot 67 Independence Layout Enugu-Nigeria in 2006. (Textbook 4)

- Basic Biology: A Didactic Approach by Jeff Odunukwe published by Academic Publishing Company, 33 Edinburgh Road, Enugu, Nigeria in 2004. (Textbook 5)

- Acquisition and Transfer of a Property in Islamic Law by Yahaya Y. Bambale, published by Malthouse Press Limited, 43 Onitana Street, off Stadium Hotel Road, Surulere, Lagos, Nigeria in 2007. (Textbook 6)

To ensure a systematic spread throughout each textbook, the data was extracted from:

1) The first page of each chapter;

2) A page from the middle of each chapter; and

3) A page at the end of each chapter.

As much as possible, each erroneous item was completely presented in the 
micro-context of use, namely, the entire sentence in which it occurred. This was done, first, to show the structural relationship between the erroneous item and other items in the sentences, and second, to reveal its full range of meaning so that those erroneous structures that needed to be accounted for in terms of semantic transfer from L1 could be readily recognized as such. The data analysis consisted of structurally analyzing each item. Structures were grouped according to their peculiar characteristics including errors and error types. The characteristics of each group were then analyzed and these characteristics were accounted for linguistically in terms of the violation of identifiable native-English constraints, or in terms of L1 and other notable influences.

\section{Summary of Findings}

The structures analyzed in this study are grammatical errors. Typographical errors were not analyzed because they are not the concern of this study. However, spelling and punctuation errors were identified and labelled as such and are different from typographical errors because they occurred more than once in the textbooks and so was not classified as typographical errors.

\subsection{Finding One}

Essentially, the identified errors were broken down as follows:

Textbook 1 has a total number of 15 chapters. In all, the book contains a total number of 2,899,000 sentences. A total number of 580 sentences were investigated and 46 of those sentences contained errors.

Textbook 2 has 13 chapters. The book contains 2,351,000 sentences. 407 sentences were examined and 155 of them contain errors.

Textbook 3 contains 7 chapters and there are a total number of 721 sentences. 184 sentences were examined and 26 of those sentences contain errors.

Textbook 4 has 8 chapters. The book contains 1,500,000 sentences. 138 sentences were investigated and 43 of them contain errors.

Textbook 5 contains 14 chapters with a total number of 1,983,000 sentences. Out of those sentences, 286 were examined and 147 of them contain errors.

Textbook 6 contains a total number of 783 sentences in 7 chapters. 129 sentences were examined and 20 of them contain errors.

The analysis revealed the following features:

\section{1) Modification Problem}

a) Noun Head Premodification

This is often characterised by:

- omission of determiners, especially the articles

- superfluous insertion of determiners

- deviation in the sequence of determiners

Omission of determiners and insertion of determiners occur in context where no serious impairment of grammar or meaning is done, but where native English usage would nevertheless not omit or insert the determiners. The insertion 
and omission of determiners in these contexts were consistent with all the examined authors.

Here are some examples from the data:

i) ${ }^{*}$ There is an African belief which regards an infant as less human or animal, a kuntu until he is able to make $\varnothing$ utterance before he is regarded as a human being, a muntu. (an)

ii) ${ }^{\star}$ This is the help rendered by $\varnothing$ tense in language. (the)

iii) ${ }^{*}$ When we speak of $\varnothing$ function of language ... (the)

iv) ${ }^{*}$ Refer to $\varnothing$ dictionary for meaning ... (the)

v) ${ }^{\star}$ In giving $\varnothing$ illustration, specific examples ... (an)

vi) ${ }^{*}$ Therefore, $\varnothing$ sentence or $\varnothing$ utterance is said to be... (a, an)

vii) ${ }^{\star} \varnothing$ Physiological variation is one based on functions and behaviours of individuals of the same species. (A)

b) Noun Head Post Modification

Here, only the relative clause post modifier showed peculiar characteristics, namely:

- too frequent use of "that" in place of who and which

- also, substitution of "that" for when and where.

The use of the relative pronoun "that" in the place of its counterparts "who" and "which" was again consistent, and occurred quite noticeably in the Business Administration and Sciences textbooks.

\section{2) Prepositions and Verb Particles}

Three distinct patterns in the use of prepositions and verb particles were revealed, namely:

- the substitution of some other prepositions and particles for the usual one

- the superfluous insertion of prepositions and particles

- the omission of prepositions and particles

a) Here, the substitution of some other prepositions for the usual ones occurs in contexts where the substitutes do not impair meaning nor sound outlandish nor appear erroneous generally. Although they may not be used by native speakers of English, their acceptability in such contexts is enhanced by the general lack of selectional-restriction rules (collocation) for pronouns in most contexts of their occurrence. Examples from the data:

i) ${ }^{\star}$ The action was a slap on the face... (in)

ii) ${ }^{\star}$ We dabbled into politics from time to time... (in, at, with)

iii) ${ }^{*}$ He did it on his freewill. (of)

b) The superfluous insertion of prepositions and particles. Here are examples from the data:

i) ${ }^{\star}$ The examination comprises of an oral test and written paper.

ii) ${ }^{*}$ At that time, the government was advocating for a two-party system...

iii) ${ }^{\star}$ The labour union, contemplating on its next move, launched a series of...

c) The omission of prepositions is not as prominent as substitution, and is in fact almost restricted to the omission of "on" before days of the week, months, years and dates generally-a clear influence of American English particularly 
noticeable in mass media, internet and Microsoft usage. Some examples from the data are:

i) ${ }^{\star}$ The president announced $-1^{\text {st }}$ January his government's second thought on the wage issue. (on)

ii) ${ }^{\star}$ It took place-Tuesday morning... (on)

iii) ${ }^{*}$ If they were flown out-Sunday, $3^{\text {rd }}$ May for a medical check-up abroad... (on)

It is very pertinent to note here that no instances of substitution, insertion or omission of verb particles are justifiable at the acrolectal stage. This is because of the functional duty the verb performs in a sentence. All the examined authors are guilty of this error, and in many cases, meanings are impaired.

\section{3) Concord}

The following characteristic variations were revealed:

- Subject-verb agreement problems

- the frequent use of one ... or the other for one ... or another

- the substitution of the reflexive pronouns themselves, ourselves, yourselves for the reciprocal each other and one another

- the use of "they" often with unspecified antecedents

- the honorific use of "they" for singular antecedents

- the frequent occurrence of the stylistic inelegant forms he/she, him/her, he or she, him or her in place of plural proforms or the generic he or him

The use of the forms he/she, him/her, he or she, him or her in the place of plural proforms or the generic he or him were not treated as errors in this study; although some gender sensitive linguists frown on such usages and regard them as deviant structures or outright errors (Ananda, 2009). The worrying aspect was that the authors were inconsistent with this usage and this was consistent with all the examined authors.

Here are a few extracts from the data:

a) ${ }^{*}$ These tissue protect plants from entry of fungi and bacteria which may be harmful to them. (these tissues protect or this tissue protects...)

b) * Many a times we give one reason or the other why we do not return good for good... (another)

c) ${ }^{\star}$ It was such a long time since they left school that when they met again they could almost not recognize themselves. (one another)

d) ${ }^{\star}$ He told the nurse at the clinic that they asked him to bring two bottles. (where, from the passage, the "they" was referring to the medical doctor.)

\section{4) Lexis}

The following peculiar characteristics were discovered:

- Frequent pluralisation of non-plural forms

- Non-pluralisation of plural forms

- Coinages, in the form of-independent coinage; acronyms; derivatives; change of word class; reduplication

- Confusion of homophones and partial homophones

- Loans in the three categories: a) those which occur because native English 
usage has no equivalents for them; b) those which have equivalent lexical items in English but continue to be used alongside them; c) and those which occur as qualifiers of other English terms.

Here, coinage, meaning extension without impairment of intelligibility and loans are marked characteristics. Ambiguous words choice which impaired meaning and legitimate English words in the wrong positions. Example: ${ }^{\star}$ potentials (potential), ${ }^{*}$ equipments (equipment), ${ }^{\star}$ Be careful not to lose the money... (lose); ${ }^{\star}$ Practice compliments theory... (complements) are such errors.

\subsection{Finding Two}

The identified erroneous structures were classified into these possible categories:

1) Lexical errors

2) Errors in the use of function words

3) Errors in sentence structure

4) Errors in concord relations

After a detailed analysis, these errors were further categorized into the following sub-types based on the violation of grammatical rules with the help of our theoretical framework.

1) Omission of Determiners before Singular Nouns

The articles, definite and indefinite, posed a major problem and were omitted before singular nouns. Some examples from the data have been given earlier above.

2) Inclusion of Redundant Elements/Reduplication

This feature occurred in three categories-

- those which involve the use of "etc" after words such as include, such as and e.g., for instance

- those which involve the use of redundant preposition

- those which involve repeating the same thing using another word or expression.

Here are some examples from the data:

a) *...e.g. writing, shorthand, Braille, etc.

b) *...newspapers and then request for the summary of...

c) ${ }^{*}$ The present situation in the country today in the...

d) ${ }^{*}$...branch include the following: Personal accident Insurance... Contractors' All Risks, etc.

e) ${ }^{\star} \ldots$ (mutual insurance associations) practised which include Age grades, social clubs, Extended family system, Isusu, etc.

f) *...other parties including: purchasing and sales contracts, construction contracts, leasing agreements, etc.

3) Restructuring of Collocations

Well known doubles or dyads were altered without any known cause.

Some examples from the data are: 
a) ${ }^{\star}$ Once man started acquiring properties for use or keeps, there must be incidents of tear and wear. (wear and tear)

b) ${ }^{*}$ Library materials, as one of the human possessions are not left out of deterioration or incidents of tear and wear and this started even early Egyptian libraries. (wear and tear)

4) Alteration of the Grammatical Property of Collocational Items

This feature occurred in five categories-

- those that involve orthographic (spelling) error

- those that involve concord error

- those that involve the misuse of prepositions and wrong word choice

- those that involve the misuse of the verb [a) using transitive verb intransitively b) using the noun instead of the verb spelling of certain verbs $c$. using stative verbs dynamically]

- those that involve the pluralisation of non-count nouns Some examples include:

a) ${ }^{\star}$ Whenever an unfamiliar word props up in a write up, or a word is used in an unfamiliar way, it is wise to look it up in a dictionary, ... (... word pops up in a write-up...)

b) *...together “i” must preceede. (precede)

c) ${ }^{*}$ Therefore, when a speaker is opportuned to play the role of speaking, he has a receiver while his receiver may become his transmitter. (...speaker has the opportunity to ...)

d) ${ }^{*}$ The student may have a topics as ... (topic)

5) Restructuring of Parallel Sentences

Some examples from the date are:

a) *...then you will know that the car needs a new battery, a tyre, and the oil should be changed. $(\mathrm{N}+\mathrm{N}+$ Clause $)$

b) ${ }^{\star}$ The new guard is strong, competent and you can depend on him. (Adj + Adj + Clause)

c) * ...he was a cheat, a liar and takes what does not belong to him. $(\mathrm{N}+\mathrm{N}+$ $\mathrm{VP})$

6) Substitution of Lexical Elements within Collocational Structures

\section{Conclusion/Recommendation}

A study of this nature, unarguably, has its own inevitable constraints. For one thing, the available data, no matter how systematically or painstakingly collected and collated, can never be representative of all the usage possibilities. The welter of data should therefore be seen more as indicators of usage patterns in some teaching materials in circulation than as an exhaustive corpus. Again, the dynamism which is an inherent characteristic of languages, places every language inevitably in a state of influx. On the other hand, grammatical descriptions and the characterisation of language features are by their nature static.

However, this study has helped to expose the knowledge that the students are 
merely the conveyor belt of lexico-syntactic errors contained in the very teaching material they use in learning. The major syntactic and lexical errors discovered and analysed are not different from those identified by previous researchers over the years in students' essays and exam scripts-Bamgbose (1971); Adekunle (1974); Adeniran (1979); Adetugbo (1977, 1979, 1984); Akere (2004); Jibril (1979); Olagoke (1981); Kujore (1985); Obilade (1984); Okoro (1992); Jowitt (1991); Israel (2012). Since the selected authors are teachers and the textbooks are those used in classroom teaching, it then clearly demonstrates that one can analyse the students' lexico-syntactic errors in tandem with such errors contained in the very material used in teaching/learning. Again, it can equally be said that while enormous progress has been made in Nigeria in areas such as technology, science, geoinformatics, politics, fashion, music and movies over the years; not much result has been recorded on English language grammar and usage especially as regards to students' achievements in the English language usage (Israel, 2012).

Having said this, the researcher therefore provides the following recommendations to help curb this negative effect of vanity publication on the educational system in Nigeria:

1) Universities' Departments of English should immediately review their programmes to embrace more language and more grammar, with emphasis on core descriptive grammar areas such as the sentence and clause (syntactic structure), verbal group, nominal group, adjectival group, adverbial group, and prepositional group. While two credits may be adequate for the rest, the syntactic structure should be allotted three or four credits because of its significance and complexity. Such improved programmes will ensure adequate grammatical knowledge, stimulate research in grammar, even among undergraduates, and positively change the orientation of research in Nigeria, which, sadly, has progressively drifted far from mainstream linguistics. A few departments of English already run programmes similar to what is advocated here, but many of them lack competent personnel for their full and effective implementation. So there is a vicious cycle of poor grammatical knowledge characterising English language teaching and research in Nigeria. A programme strengthened on its grammatical contents should be able to break that cycle. After all, no one can teach another a language whose description he does not know; and, none still can investigate an aspect of a language in which he lacks the prerequisite descriptive knowledge.

2) Faculties of education should similarly review their English teacher-education programmes to enable their students to benefit maximally from the improved programmes. Special courses on English language and communication skills should be mounted for all graduate teacher-in-training to raise their competence level and equip them for the challenges of language use. With improved English degree programmes, students who will become professional teachers/writers in the future will be guaranteed a solid foundation in the language because they will be taught by more knowledgeable teachers. In this regard, an 
adequate descriptive grammatical model based on an equally adequate grammatical theory should be adopted to ensure accurate and systematic description and presentation of grammatical forms and their functions. The scope of grammar teaching should be broadened to reflect the complexities therein.

3) Undergraduates in Nigeria, irrespective of the discipline, should be taught English Grammar \& Usage and Communication/Writing Skills from the first year to the last year of their programme. A sort of extended unit should be carved out from the Department of English to run this programme. A situation where undergraduates are exposed to Use of English only in the first year of their programme, when many of them are yet unsettled for a serious academic work, is totally unproductive and ineffective for teaching/learning of English usage.

4) The government-at the federal, state and local levels-in collaboration with the Department of English in Nigerian universities should establish a functional board that will monitor the activities of the publishing houses in Nigeria. The board should see to it that publishing houses (public and private) have well-trained two sets of editors-those who edit for content and those who edit for language. The board must insist that recruitment of editors based on the face value of certificates tendered should be stopped. Pre-recruitment tests should be conducted to determine the level of editors' writing competence; and, this is without prejudice to whatever other tests the employer may wish to administer. On no account should unsuccessful candidates be recommended for appointment, irrespective of their performance in other tests. Although this measure appears tough, the reality is that no editor can be effective if he/she is not competent in the language in use. Editors already in service can benefit from regular in-service-training within the country and abroad, while those who cannot improve on their competence in English should be redeployed to departments where they will have nothing whatsoever to do with the business of writing/editing. The board should also insist that the general working condition of editors is regularly reviewed and improved upon. These measures are necessary for the attainment of excellence in the area of education in Nigeria.

\section{Conflicts of Interest}

The author declares no conflicts of interest regarding the publication of this paper.

\section{References}

Adekunle, M. A. (1974). The Standard Nigerian English in Sociolinguistic Perspectives. Journal of Nigerian English Studies Association (JNESA), 6, No. 1.

Adeniran, A. (1979). Nigerian Elite English as a Model of Nigerian English. In E. Ubahakwe (Ed.), Varieties and Functions of English in Nigeria (pp. 31-44). Ibadan: NESA/OUP.

Adetugbo, A. (1977). Nigerian English: Fact or Fiction. Lagos Notes and Records, 6, $128-141$. 
Adetugbo, A. (1979). Appropriateness and Nigerian English. In E. Ubahakwe (Ed.), Varieties and Functions of English in Nigeria (pp. 11-23). Ibadan: NESA/OUP.

Adetugbo, A. (1984). The English Language in the Nigerian Experience. Inaugural Lecture, Lagos: Lagos University Press.

Akere, F. (2004). Nigerian English in Sociolinguistic Perspective: Users, Uses and Emerging Varieties. In A. B. K. Dadzie, \& S. Awonusi (Eds.), Nigerian English: Influences and Characteristics (pp. 39-40). Lagos: Concept Publications.

Ananda, S. (2009). Error Analysis: A Pragmatic Approach. http://www.thdl.org/texts/reprints/contributions/CNAS06020/.pdf

Awonusi, S., \& Babalola, E. A. (Eds.) (2004). The Domestication of English in Nigeria a Festschrift for Abiodun Adetugbo at 65. Lagos: University of Lagos Press.

Bamgbose, A. (1971). The English language in Nigeria. In J. Spencer (Ed.), The English Language in West Africa (p. 28). London: Longman.

Bamgbose, A., Banjo, A., \& Thomas, A. (Eds.) (1995). New Englishes: A West African Perspective. Ibadan: Mosuro Printers.

Chomsky, N. (1957). Syntactic Structures. The Hague: Mouton. https://doi.org/10.1515/9783112316009

Corder, S. P. (1967). The Significance of Learners Error. In J. Richards (Ed.), Error Analysis: Perspectives on Second Language Acquisition. London: Longman.

Crystal, D. (1997). The Cambridge Encyclopedia of Language (2nd ed.). Cambridge: Cambridge University Press.

Dadzie A. B. K. (2004). The Concept of Nigerian English. In A. B. K. Dadzie, \& S. Awonusi (Eds.), Nigerian English: Influences and Characteristics (pp. 20-23). Lagos: Concept Publications.

Darus, S., \& Subramaniam, K. (2009). Error Analysis of the Written Essays of Secondary School Students in Malaysia: A Case Study. European Journal of Social Sciences, 8, 483-495.

Dulay, H., \& Burt, M. (1974). Errors and Strategies in Child Second Language Acquisition. TESOL Quaterly, 8, 129-136. https://doi.org/10.2307/3585536

Egyir-Hagan, M. M. (2019). The Use of Tenses: A Study of Second and Third Language Students of English at the Ghana Institute of Languages. M.A. Thesis, Winneba: University of Education, Winneba.

Emmaryana, F. (2010). An Analysis on the Grammatical Errors in the Students' Writing (A Case Study of the First Year Students of SMA Negeri I Cigudeg-Bogor). Undergraduate's Thesis, Jakarta: UIN Syarif Hidayahfullah.

Faleke, V. O., Abaya, S. A., \& Ahamed, A. (2016). Teaching Medical Register in ESL Environment in Technological Age: A Teacher's Innovation. In A. Olatunde, N. B. Upah, P. Onah, \& A. Oreoluwa (Eds.), Linguistics, Language and Literature a Festschrift for Gbenga Solomon Ibileye (pp. 41-44). Lokoja: IzymacFontz.

Grieve, D. G. (1966). English Language Examining. Lagos: West African Examinations Council.

Heydari, P. (2012). Theory and Practice in Language Studies. Tampere: Academy Publisher.

Israel, P. C. (2012). A Lexico-Syntactic Analysis of Errors in Selected Textbooks Written by Nigerian Authors. Unpublished PhD Thesis, Lagos: University of Lagos.

James, C. (1998). Errors in Language Learning and Use: Exploring Error Analysis. New York, NY: Longman.

Jibril, M. (1979). Regional Variation in Nigerian Spoken English. In E. Ubahakwe (Ed.), 
Varieties and Functions of English in Nigeria (pp. 43-53). Ibadan: African University Press \& Nigeria English Studies Association.

Jowitt, D. (1991). Nigerian English Usage: An Introduction. Lagos: Longman, Nigerian PLC.

Kachru, B. B. (1982). The Pragmatics of Non-Native Varieties of English. In L. E. Smith (Ed.), English for Cross-Cultural Communication (pp. 15-39). Heidelberg: Springer. https://doi.org/10.1007/978-1-349-16572-8_2

Ker, A. (2009). Problems of the Book Industry and Educational Development in Nigeria: Lessons for the 21st Century. http://www.unilorin.edu.ng/unilorin/journals/education

King-Aribisala, K. (2012). Destination Freedom: Vehicle, Symbolism in Black Literature. Lagos: Nigeria University of Lagos Press.

Kujore, O. (1985). English Usage: Some Notable Nigerian Variations. Ibadan: Evans Brothers.

Obilade, T. (1984). On the Nativization of the English Language in Nigeria. Anthropological Linguistics, 26, 170-185.

Odumah, T. O., \& Ohiare, M. U. (2016). English Language Teaching in a Globalized and Digital Age: Implications for Teacher Preparation and Professional Development Nigeria. In A. Olatunde, N. B. Upah, P. Onah, \& A. Oreoluwa (Eds.), Linguistics, Language and Literature a Festschrift for Gbenga Solomon Ibileye (pp. 21-22). Lokoja: IzymacFontz.

Okoro, O. (1980). Lexical and Syntactic Deviations in the English of Igbo Speakers: A Study of Freshmen English in Two Nigerian Universities. Unpublished M. Phil Thesis, Lagos: University of Lagos.

Okoro, O. (1992). Characterizing the Lects of Nigerian English: A Descriptive Analysis of Their Syntax and Lexis. Unpublished Ph.D. Thesis, Lagos: University of Lagos.

Olagoke, D. O. (1981). Lexical Deviations in Nigerian English. JLAC, 3 \& 4, 3537.

Richards, J. C. (1971). Error Analysis and Second Language Strategies. Language Science, 17, 12-22.

Rotimi, T. (2012). Language and Mobile Telecommunication in Nigeria: SMS as a Digital Lingual-Cultural Expression. Ile-Ife: Obafemi Awolowo University Press.

Ubahakwe, E. (1979). Varieties and Functions of English in Nigeria. Ibadan: NESA/OUP. 